\title{
Human chorionic gonadotropin with C-elongated $\alpha$-subunit retains full receptor binding and partial agonist activity
}

\author{
Hamani Marichatou, Nadine Martinat, Florian Guillou and Yves Combarnous \\ Laboratoire de Physiologie de la Reproduction des Mammifères Domestiques, INRA-CNRS URA1291 37380 Nouzilly, France \\ (Correspondence should be addressed to Y Combarnous; Email: combarno@.tours.inra.fr) \\ (H Marichatou is now at Université Abdou Moumouni, Faculté d'Agronomie, Niamey, Niger)
}

\begin{abstract}
Objective: To test whether extension of the C-terminus of human chorionic gonadotropin (hCG) $\alpha$-subunit $(\mathrm{h} \alpha)$ alters the bioactivity of the recombined $\alpha \beta$ heterodimer.

Design: The stop codon of $\mathrm{h} \alpha$ was mutated to produce a 24 amino acid extension.

Methods: The extended h $\alpha\left(\alpha_{+24}\right)$ was co-expressed with hCG $\beta$ in COS-7 cells and the receptor binding and in vivo bioactivity of the secreted hormone was compared with its wild-type counterpart.

Results: This extension did not impair the binding of hCG to rat LH/CG receptors and provoked a sixfold reduction in its stimulatory activity of testosterone secretion in rat Leydig cells.

Conclusions: The extension of $\alpha$ by itself does not lead to inhibition of the $\alpha \beta$ heterodimer to LH receptors but the structure of the extension appears to play an important role. It is thus possible that one-chain hCG chimeras with the $\beta \mathrm{N}$-terminus fused to the $\alpha \mathrm{C}$-terminus might be active.
\end{abstract}

European Journal of Endocrinology 142 402-405

\section{Introduction}

Human chorionic gonadotropin (hCG) is a member of the glycoprotein hormone family which also includes luteinizing hormone (LH), follicle-stimulating hormone (FSH) and thyrotropin (TSH). These hormones are heterodimeric and consist of two different non-covalently linked glycoprotein subunits: a common $\alpha$-subunit and a hormone-specific $\beta$-subunit. Only the $\alpha \beta$ dimers, but not the dissociated subunits, exhibit high affinity towards the receptors and the specificity of binding is directed by the $\beta$-subunit. Nevertheless, the common $\alpha$-subunit has been shown to play a crucial role in both high affinity binding (1) and signal transduction (2). In this respect, it has been shown by site-directed mutagenesis that the C-terminal residues of the $\alpha$-subunit of hCG $\left(\mathrm{Tyr}^{88}\right.$-TyrHis-Lys-Ser ${ }^{92}$ ) are involved in its bioactivity. Indeed, truncations of this portion $(3,4)$ as well as many specific mutations of its individual residues (3-6) lead to reduced stimulatory activity in spite of unchanged binding activity.

In the present work, we produced a mutant hCG with an $\alpha$-subunit elongated by 24 residues beyond the terminal $\mathrm{Ser}^{92}$ residue through mutation of the stop codon in order to evaluate (1) the possible role of the terminal carboxyl group of the $\alpha$-subunit in hCG binding and signal transduction and (2) the functional consequences of a carboxy extension of the $\alpha$-subunit in the scope of producing an active ${ }_{\mathrm{NH} 2} \alpha-\beta_{\mathrm{COOH}}$ single-chain hCG.

\section{Materials and methods}

\section{Plasmid constructs}

The cDNAs encoding the wild-type hCG $\alpha$-subunit and the elongated $\alpha$-subunit $\left(\alpha_{+24}\right)$ were kindly given by $\mathrm{Dr}$ J J Rémy (INRA, Jouy-en-Josas, France). The $\alpha_{+24}$ cDNA lacks the stop codon of the wild-type $\alpha$ cDNA and this leads to translation of the $3^{\prime}$ UTR region down to the next stop codon. The cDNA sequence of the construct was determined on applied model (373A) nucleotide sequencer and the deduced amino acid sequence of the C-terminal extension in $\mathrm{h} \alpha_{+24}$ was Lys-Val-Glu-Gly-SerSer-Ile-Pro-Thr-Ser-Ser-Ala-Pro-Ala-Gly-Arg-Gly-ArgAsp-Ser-Arg-Gly-Ser-Leu. The wild-type hCG $\beta$ cDNA in the $\mathrm{pM}^{2}$ vector was a gift from Dr I Boime (Washington University, St Louis, MO, USA). All cDNAs were inserted at the unique HindIII site in the pCDM8 (InVitrogen) mammalian expression vector as previously described (7). All constructs were amplified in MC1061/P3 bacteria (InVitrogen, Groningen, The Netherlands) and purified using the maxiprep kit (Qiagen, Coutaboeuf, France).

\section{Transient expression of recombinant hormones in COS-7 cells}

The COS-7 cells (ATCC-CRL 1651) maintained at $37^{\circ} \mathrm{C}$ under $5 \% \mathrm{CO}_{2}$ in humidified atmosphere in Dulbecco's modified Eagle's medium (7) were co-transfected with 

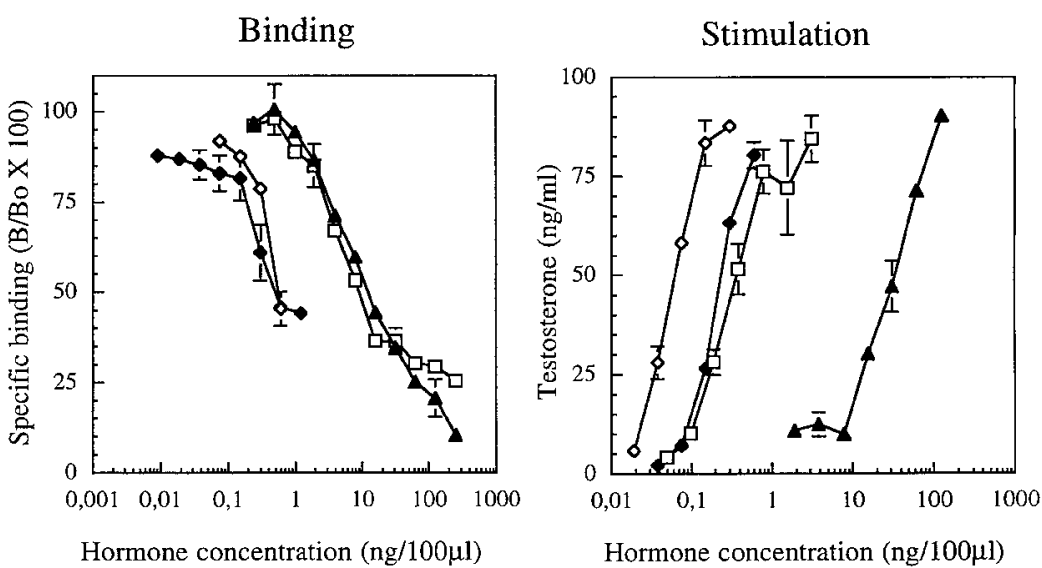

\author{
Figure 1 Left: radioreceptor assay of pituitary \\ $\mathrm{pLH}(\boldsymbol{\Lambda})$, urinary hCG $(\square)$, recombinant \\ h $\alpha$.hCG $\beta(\diamond)$ and recombinant h $\alpha_{+24} \cdot \mathrm{hCG} \beta(\diamond)$ \\ using rat testicular membrane fraction and \\ ${ }^{125}$ I-oLH. Right: stimulation of testosterone \\ secretion in rat Leydig cells by the same \\ hormones (same symbols). Concentrations of \\ hormones are based on their immunoactivity \\ measured by EIA. The bars show S.D.
}

$2 \mu \mathrm{g}$ of one vector encoding a h $\alpha$-subunit $\left(\alpha\right.$ or $\left.\alpha_{+24}\right)$ and $2 \mu \mathrm{g}$ of the vector encoding the wild-type hCG $\beta$-subunit. This was performed at $65 \%$ confluency in $6 \mathrm{~cm}$ Petri dishes using the calcium phosphate precipitation procedure (7). Control cells were transfected with the empty pCDM8 expression vector. The supernatants were collected and kept frozen at $-20^{\circ} \mathrm{C}$ until assays.

\section{Natural hormones}

Partially purified urinary hCG (1000 IU/vial) was purchased from Intervet (Oss, Holland) and its immunoactivity was checked in the specific EIA described below against the WHO international reference preparation. The concentrations of hCG were calculated on the basis of $15000 \mathrm{IU} / \mathrm{mg}$ for the pure hormone. Porcine LH (pLH CY1354; $2.0 \times$ NIH LH S1) and ovine LH (oLH CY1086; $3.5 \times \mathrm{NIH}$ LH S1) were purified in our laboratory. The radioiodination of oLH was performed using the chloramine $\mathrm{T}$ oxidation method (8).

\section{Hormone assays}

Quantification of expression was performed by an enzyme immunoassay (EIA) specific for the hCG $\alpha \beta$ heterodimer with a polyclonal antibody raised in the rabbit against hCG (M P Dubois, Nouzilly) using a previously published protocol (9). In this assay, the cross-reactions of the free $\mathrm{h} \alpha$ - and hCG $\beta$-subunits are 0.1 and $0.3 \%$ respectively relative to hCG, showing that the antibody is heterodimer-specific. In addition, the $\alpha \beta$ and $\alpha_{+24} \beta$ heterodimers exhibit parallel competition curves, indicating that the +24 extension at the $\mathrm{C}$ terminus of $\mathrm{h} \alpha$ probably does not affect the conformation of the heterodimer. The binding activity of the recombinant dimers was measured by a radioreceptor assay using rat testicular membranes and radioiodinated oLH $\left({ }^{125} \mathrm{I}-\mathrm{oLH}\right)$ and their in vitro bioactivity was measured by stimulation of testosterone secretion in rat Leydig cells (10).

\section{Results}

Figure 1 shows the dose-response curves of inhibition of ${ }^{125} \mathrm{I}-\mathrm{oLH}$ binding to rat testicular membranes (left panel) and testosterone secretion in rat Leydig cells (right panel) by the $\alpha \beta$ and $\alpha_{+24} \beta$ dimers as compared with highly purified urinary hCG and pituitary pLH. Table 1 shows the calculated potencies of the four molecules in the two assays and the ratios between the two assays. The recombinant hCG $\alpha_{+24} \beta$ dimer exhibits unchanged binding activity to the LH receptor compared with the $\alpha \beta$ dimer. Its potency in the stimulation of testosterone secretion is sixfold less than that of wildtype recombinant hCG $(\alpha \beta)$. The recombinant wild-type hCG $(\alpha \beta)$ exhibits a tenfold higher activity than urinary hCG in the two assays. We previously observed the same difference between recombinant and natural hormones for equine $\mathrm{LH}$, equine CG and porcine $\mathrm{LH}$ when the former were produced in either CHO, COS-7 or 293 cells (N Martinat, F Guillou \& Y Combarnous unpublished data). The $\alpha_{+24} \beta$ dimer, like pLH, had no antagonistic activity on the secretion of testosterone stimulated by hCG in rat Leydig cells (not shown).

\section{Discussion}

In the present work, we have shown that the elongation of the $\alpha$-subunit of hCG by 24 amino acid residues does not impair its binding to rat $\mathrm{LH}$ receptors. This shows

Table 1 Potency of the natural and recombinant hormones in the radioreceptor assay and stimulation of testosterone secretion by rat Leydig cells.

\begin{tabular}{lccc}
\hline Hormone & $\begin{array}{c}\text { Binding } \\
(B)\end{array}$ & $\begin{array}{c}\text { Stimulation } \\
S\end{array}$ & $S / B$ \\
\hline pLH & 1 & 1 & 1 \\
hCG & 2.1 & 111 & 53 \\
$\mathrm{~h} \alpha \cdot \mathrm{hCG} \beta$ & 26 & 572 & 22 \\
$\mathrm{~h} \alpha+24 \cdot \mathrm{hCG} \beta$ & 26 & 94 & 3.6 \\
\hline
\end{tabular}


that the additional peptide portion does not interfere either with the combination of subunits or with the association of the so-formed dimer with the LH receptor. These data contrast with those of Furuhashi et al. (11) who produced an hCG chimera with an additional $\beta$ carboxyterminal peptide (hCG $\beta$-CTP) fused to the $\mathrm{C}$ terminus of the $\alpha$-subunit. This elongated $\alpha$-subunit (h $\alpha$-CTP) recombined efficiently with wild-type hCG $\beta$ subunit but the so-formed dimer exhibited very low binding activity to the human $\mathrm{LH}$ receptor expressed in the human fetal kidney 293 cell line $(<5 \%$ relative to wild-type hCG).

Thus, the +24 peptide does not exert any inhibitory activity on hCG binding to rat LH receptors when present at the C-terminus of the $\alpha$-subunit. This extension is only slightly shorter than the $\beta$-CTP $(28$ amino acid residues) but the latter is known to bear $O$ saccharide chains on four of its eight serine residues $\left(\operatorname{Ser}^{121}, 127,132,138\right)$ in the natural hCG molecule (12) and was also found to be $O$-glycosylated when fused to the C-terminus of the $h \alpha$-subunit (11). Multiple $O$ glycosylation in segments of proteins impedes the folding of these regions, leading to bulky extended flexible structures (13). It is thus very likely that the bulky O-glycosylated CTP at the C-terminus of the $\alpha$ subunit hinders the access of the dimer to the receptor. It can thus be hypothesized that the +24 peptide at the same location does not diminish the binding of the dimer to the receptor because of less steric hindrance compared with $\beta$ CTP. The observed full binding activity of the $\alpha_{+24} \beta$ dimer also demonstrates that the $\alpha$ carboxyl group of the $\mathrm{C}$-terminal $\mathrm{Ser}^{92}$ residue is not crucial for high-affinity binding to rat $\mathrm{LH}$ receptors.

However, it cannot be ruled out from the present data using rat LH receptors and those of Furuhashi et al. (11) with human receptors that extension of the h $\alpha$-subunit, with $\beta$-CTP or +24 peptide, leads to binding inhibition of hCG to the human receptors but not to the rat receptors. This is in keeping with the observation of Jia et al. (14) that the recombinant human LH receptor exhibits a very narrow specificity since it binds only the human gonadotropins hLH and hCG but not the equine, rat or ovine LHs. In contrast, LHs and CGs from all species tested bind to the rat testicular $\mathrm{LH}$ receptor in vitro $(15,16)$ but, as far as we know, the binding of non-human gonadotropins to natural human $\mathrm{LH}$ receptors from testis or ovary has not been studied; therefore it is impossible to ascertain whether the difference arises from the species origin of the receptors (human vs rat) or from the cells in which they are expressed (L293 vs Leydig).

The potency of the $\alpha_{+24} \beta$ dimer in the stimulation of testosterone secretion in rat Leydig cells is $16 \%$ that of the $\alpha \beta$ dimer. This indicates that the presence of an additional sequence at the $C$-terminus of the $\alpha$-subunit does interfere with signal transduction but, nevertheless, does not suppress it completely. Previous studies have shown that truncations or mutations in this location also diminish signal transduction (3-6). Moreover, reciprocal mutagenesis of Lys $^{91}$ of the hCG $\alpha$-subunit and of Asp ${ }^{397}$ of the exoloop 1 of the $\mathrm{LH}$ receptor suggests that these residues interact for receptor activation but not for highaffinity binding (17). It is likely that the additional +24 peptide at the $\mathrm{C}$-terminus of the $\alpha$-subunit diminishes the flexibility of this region and consequently slows down its adaptation with exoloop 1 of the receptor and subsequent activation of the receptor. It is interesting to point out that in spite of the unfavorable effect of the extension of the $\alpha$-subunit, the stimulatory activity of the $\alpha_{+24} \beta$ dimer remains higher than that of pLH. After binding, hCG exhibits a much higher transduction efficiency than pLH in rat Leydig cells (15). In order to get a better comprehension of the molecular mechanism of the LH/CG receptor activation, it will be necessary to determine whether the elongation of the $\alpha$-subunit only affects the 'superactivity' of hCG or also affects the 'normal' activity of pLH. Moreover, the retention of bioactivity in hCG with C-elongated $\alpha$-subunit opens new ways in the production of active gonadotrope molecules for the control of fertility. In particular, active single-chain gonadotropins with their $\alpha$ - $\beta$-subunits fused in this order should be synthesized in addition to the different $\beta-\alpha$ molecules already described (18-20).

\section{Acknowledgements}

We are indebted to Dr Irving Boime (University of Washington, St Louis, MO, USA) and to Dr Jean-Jacques Rémy (INRA, Jouy-en-Josas, France) for the kind gift of the cDNAs of the hCG subunits and to François Lecompte (INRA, Nouzilly, France) for hCG EIAs. Thanks are also due to Dr François Grosclaude (INRA, Paris, France) for the attribution of an INRA grant to H M.

\section{References}

1 Combarnous Y. Molecular basis of the specificity of binding of glycoprotein hormones to their receptors. Endocrine Reviews 1992 13 670-691.

2 Ryu K-S, Ji I, Chang TH \& Ji TH. Molecular mechanism of LH/CG receptor activation. Molecular and Cellular Endocrinology 1996 125 93-100.

3 Chen F, Wang Y \& Puett D. The carboxy-terminal region of the glycoprotein hormone alpha-subunit: contributions to receptor binding and signaling in human chorionic gonadotropin. Molecular Endocrinology 19926 914-919.

4 Yoo J, Zeng H, Ji I, Murdoch WJ \& Ji TH. COOH-terminal amino acids of the alpha subunit play common and different roles in human choriogonadotropin and follitropin. Journal of Biological Chemistry 1993268 13034-13042.

5 Yoo J, Ji I \& Ji TH. Conversion of lysine 91 to methionine or glutamic acid in human choriogonadotropin alpha results in the loss of cAMP inducibility. Journal of Biological Chemistry 1991266 17741-17743.

6 Zeng H, Ji I \& Ji TH. Lys91 and His90 of the alpha-subunit are crucial for receptor binding and hormone action of folliclestimulating hormone (FSH) and play hormone-specific roles in FSH and human chorionic gonadotropin. Endocrinology 1995 $1362948-2953$. 
7 Chopineau M, Martinat N, Troispoux C, Marichatou H, Combarnous Y, Stewart F et al. Expression of horse and donkey LH in COS-7 cells: evidence for low FSH activity in donkey LH compared with horse LH. Journal of Endocrinology $1997152371-377$.

8 Greenwood FC, Hunter WM \& Glover JS. The preparation of ${ }^{125} \mathrm{I}-$ labelled human growth hormone of high specific radioactivity. Biochemical Journal 196389 114-123.

9 Lecompte F \& Combarnous Y. Enzyme immunoassay (EIA) for equine chorionic gonadotropin/pregnant mare serum gonadotropin (eCG/PMSG). Journal of Immunoassays 199213 483-493.

10 Guillou F, Martinat N \& Combarnous Y. Rapid in vitro desensitization of the testosterone response in rat Leydig cells by sub-active concentrations of porcine luteinizing hormone. FEBS Letters $19851846-9$

11 Furuhashi M, Shikone T, Fares FA, Sugahara T, Hsueh AJW \& Boime I. Fusing the carboxy-terminal peptide of the chorionic gonadotropin (CG) beta-subunit to the common alpha-subunit: retention of $O$-linked glycosylation and enhanced in vivo bioactivity of chimeric human CG. Molecular Endocrinology 19959 54-63.

12 Bousfield GR, Butnev VY, Gotschall RR, Baker VL \& Moore WT. Structural features of mammalian gonadotropins. Molecular and Cellular Endocrinology $19961253-19$.

13 Jentoft N. Why are proteins O-glycosylated? Trends in Biochemical Sciences $151990291-294$.

14 Jia X-C, Oikawa M, Bo M, Tanaka T, Ny T, Boime I \& Hsueh AJW. Expression of luteinizing hormone (LH) receptor: interaction with $\mathrm{LH}$ and chorionic gonadotropin from human but not equine, rat and ovine species. Molecular Endocrinology 19915 759-768.
15 Combarnous Y, Guillou F \& Martinat N. Functional states of the luteinizing hormone/choriogonadotropin-receptor complex in rat Leydig cells. Journal of Biological Chemistry $19862616868-$ 6871.

16 Apparailly $\mathrm{F} \&$ Combarnous Y. In vitro potency of synthetic peptides with authentic or randomized 75-89 sequence of the $\alpha$ subunit of human, equine and porcine glycoprotein hormones. Endocrine 19942 659-663.

17 Ji I, Zeng H \& Ji TH. Receptor activation of and signal generation by the lutropin/choriogonadotropin receptor. Cooperation of Asp397 of the receptor and alpha Lys91 of the hormone. Journal of Biological Chemistry $199326822971-22974$.

18 Sugahara T, Pixley MR, Minami S, Perlas E, Ben-Menahem D, Hsueh et al. I. Biosynthesis of a biologically active single peptide chain containing the human common alpha and chorionic gonadotropin beta subunits in tandem. Proceedings of the National Academy of Sciences of the USA 199592 2041-2045.

19 Narayan P, Wu C \& Puett D. Functional expression of yoked human chorionic gonadotropin in baculovirus-infected insect cells. Molecular Endocrinology 1995 91720-1726.

20 Heikoop JC, Van Beuningen-De Vaan MJACM, Van Den Boogaart P \& Grootenhuis PDJ. Evaluation of subunit truncation and the nature of the spacer for single chain human gonadotropins. European Journal of Biochemistry 1997245 656-662.

Received 11 August 1999

Accepted 11 November 1999 